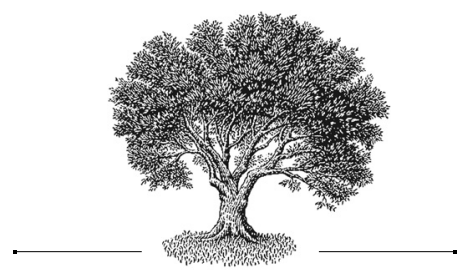

\title{
On Proto-Slavic Oath Formulas ${ }^{1}$
}

\section{О праславянских клятвенных формулах}

\section{Jasmina}

\section{Grković-Major}

University of Novi Sad

Faculty of Philosophy,

Novi Sad

\section{Ясмина}

Грекович-Мейджор

Университет Нового Сада, философский факультет, Новый Сад

\section{Abstract}

This paper deals with Slavic oath formulas containing the phrases 'stand firm' and 'hold firm', found mostly in peace treaties. The analysis carried out on the rich corpus of Old Serbian charters written in the vernacular and followed by a comparison with the data from Old Russian. The research is an attempt to reconstruct their possible Proto-Slavic structure, both linguistic and conceptual.

After presenting the relevant data, the author reconstructs the following ProtoSlavic formulas: *stojati tvrbdo/krěpsko vb/na klętvě (kz) komu 'stand firm in/on the oath toward someone', *drıžati tvrıdo/krěpsko klętvo $(k z)$ komu 'hold firm the oath toward someone'. Both Serbian and Russian charters show lexical variations in the prepositional phrase and in the adverbial modifier of the formulas, which testify to their semantic compositionality.

The etymology of their basic lexical constituents ( ${ }^{*}$ stojati, ${ }^{*} d r b z ̌ a t i,{ }^{*} t v r z d o,{ }^{*} k r e ̌ p b k o$ ) indicates that 'immobility, firmness' is their core meaning, *drbžati 'make immobile $>$ hold' being just a transitive version of *stojati 'be immobile > stand'. The

1 This paper resulted from research on the project "The history of the Serbian language" (178001) financed by the Ministry of Science of the Republic of Serbia. See also: GRKOVIĆ-MAJOR 2008; 2010a. 
concrete, physical concepts 'stand' and 'hold' were mapped into the target domain of the abstract ones ( $>$ 'exist' and 'keep, have'). They represent the embodied experience and speak in favor of Embodied Realism. Indo-European parallels show that 'stand' and 'hold' belong to some of the basic Indo-European (although not just Indo-European) conceptual metaphors, having a deep cultural motivation.

These notions were so deeply rooted into the conceptual apparatus that they survived the change of cultural codes, becoming an integral part of the oath in Christian times. As time went by, they were secularized and reduced to phraseological units. They still exist today, even with the same lexical constituents as in the medieval charters, e.g. Serb. držati X (reč, obećanje, veru), Russ. sderžat'X (dannoe slovo, kljatvu), stojat' na X = tverdo deržat'sja X (ubeždenija, mnenija).

\section{Keywords}

historical and cognitive linguistics, formulaic phrases, oath formulas, ProtoSlavic, Serbian, Russian, medieval charters, peace treaties.

\section{Introduction}

The goal of formulaic phrase reconstruction is, on one hand, to reveal the syntactic-semantic models which are specific for different areas of social communication, their pragmatic and functional aspects, even proto-texts or text fragments. On the other hand, the goal would be to understand the universal and/or culturally specific conceptual models which lay behind them, since these formulas are "the expression of an underlying semiotic system" [WATKINS 1992: 393].

Cognitive linguistics emphasizes that the investigation of idioms and formulaic sequences reveals the important elements of the human conceptual structure [GIBBS 2007: 721]. Yet, dealing mainly with formulas in the contemporary linguistic systems, it is often restricted by the level of the semantic transparence of their lexical constituents. We argue that understanding a deeper motivation of many formulaic expressions is possible only in a comparative and diachronic perspective, in which one of the important aspects is etymological analysis [MOKIENKo 2010], which helps us to access the primary conceptual building blocks of a formula. Moreover, if we are to postulate certain concepts as universal, or even culturally specific, we have to broaden our investigation to the deeper chronological levels, keeping in mind that the structure of today's linguistic systems is determined by their development and cannot be explained without taking the previous synchronic strata into account.

The aim of this paper is to offer insight into Proto-Slavic oath formulas. The reconstruction of Proto-Slavic legal terminology has so far drawn less attention than the reconstruction of the language of myth and poetry [IvANOv, TOPOROV 1974; LOMA 2002]. The biggest contribution in the area of legal terminology was given by Vjač. Vs. Ivanov and V. N. Toporov [e.g. Ivanov, TopoRov 1978; 1981], for which the main sources were East Slavonic data. The 
South Slavic situation has been less often studied [KATIČIĆ 1985; 1989-90, GRKOVIĆ-MAJOR 2008], although it represents a valuable source for the study of Proto-Slavic legal language.

The research is primarily based on the rich corpus of Old Serbian charters written in the vernacular, ${ }^{2}$ in comparison with Old Russian data. ${ }^{3}$ Giving some Indo-European parallels, we will try to reconstruct their possible Proto-Slavic structure, both linguistic and conceptual. This might also contribute to the reconstruction of the Proto-Indo-European sources of these formulaic expressions since, as noted by C. WATKINS [1989: 793], "a proper linguistic theory must be able to account for the creativity of human language; but it must also account for the possible long-term preservation of surface formulaic strings in the same or different linguistic traditions over millennia."

\section{The Importance of the Oath}

The study of archaic formulas implies their analysis in the frames of a syncretic cultural model, whose deep motivation was manifested at all levels of existence: in mythology, ritual, poetry, social structure etc. [IvANov, TopoROV 1978: 222]. The foundation of such a cultural system was magical thinking, in which the ritual was an integral part of reality, and the very existence of the world and society depended on conducting it properly, while the word spoken during it was not just a linguistic sign but had an executive force [KASIRER 1985: 50-51]. The same principle is present in Indo-European poetic language, in which "the proper form of a hymn, the proper ordering of ritual speech, compels the divinity to grant the wishes of the maker or commissioner of the hymn" [WATKINS 1995: 91].

Since in magical thinking words have a creative force, the essential component in Indo-European law was the formulaic pronouncement: "Ce n'est pas le faire, mais toujours le prononcer qui est constitutif du «droit»" [BENVENISTE 1969, II: 114]. In the Avesta, when asked about how many types of contract existed, Ahura Mazda answered that there were six of them, the first one being the contract of words [ZA I: 34]. Its crucial part was an oath, a solemn and binding act in Indo-European societies: "On comprend que Contrat et Serment aient constitué aux yeux des Aryens les deux piliers de l'ordre social et cosmique, les deux étant liés” [Haudry 1981: 66]. ERnout, MeILlet [1951: 329] explain the Lat. ius in the following way: "Le mot a dû signifier a l'origine formule religieuse qui a force de loi". Not abiding to it was punishable by death: the Scythians would punish a perjurer by decapitation [HER. 4.68], the Greek public oaths invoked destruction for perjurers [FARAONE 2005: 144-145], in

2 The corpus consists of [MS], [SSA], [SPP] and [ZS].

3 The corpus consists of [DDG], [GVNP], [LAVR.], [POL], [SG] and [VPL]. 
Albanian epic poetry "death comes after the oath is broken” [Mićović 1981] etc. The written Indo-European tradition reflects the same view. The peace treaty between the Hittite king Hattušilli III and Ramesses II, after a long list of gods and goddesses who were invoked as witnesses, states the following: "as to him who shall not keep them, a thousand gods of the land of Hatti and a thousand gods of the land of Egypt shall destroy his house, his land and his servants" [LANGDON, GARDINER 1920: 197]. And Hesiod writes that "the Erinyes assisted at the birth of Horcus (Oath) whom Eris (Strife) bare to trouble the forsworn" [HEs. 802-804].

Since the oath was of vital importance in Indo-European societies, ${ }^{4}$ ritual speech was strictly ordered. It was preserved by the repetition of formulaic phrases, in which the lexical constituents may have undergone lexical variation over time. ${ }^{5}$ However, the variation was always within the same conceptual domain and did not affect the conceptual basis of the formulas.

\section{Proto-Slavic Oath Formulas}

Early Christianity did not approve of the ritual of swearing. In the New Testament Jesus is clearly against it: "But I say unto you, swear not at all; neither by heaven; for it is God's throne" (Mt. 5:34). Later in the third and fourth centuries the majority of the church fathers spoke out against swearing and only later was it accepted by the Church [STANOJEvić 1922: 2]. Being obviously of vital importance, this pre-Christian custom finally won its place in the new cultural code. Justinian's decree from 535 AD established the oath which all civil servants had to give, swearing by God, Christ, the Holy Spirit, the Virgin Mary etc. This formula first entered the Byzantine charters, and from there the papal and other western charters, as well as those in Slavia orthodoxa [STANOJEVIĆ 1922: 4].

However, the source of this oath lay in pagan times. Its structure was inherited from Proto-Indo-European days and this is probably why it found fertile ground in all the communities. Pagan oaths, deeply rooted through thousands of years of practice, were kept by being adapted, thus surviving not only in the traditional culture but in the official documents of medieval Christian rulers and noblemen, too. Let us look at the Slavic situation.

Oath formulas which were lexically marked by the old religion were adapted by the replacement of their lexical constituents. The Proto-Indo-European

4 For a broader survey of the oath and swearing (in the sense of taking a vow) from ancient to modern times and some of its universal characteristics in different societies see [ERE 9: 430-438]. We are, however, focused here on Slavic as a branch of IndoEuropean.

5 Cf. the variations in the formula "hero overcome death" [WATKIns 1995: 391-397]. 
formula "to swear by god"6 [WATKINS 1989: 791-792; WEST 2007: 199-201] was adapted by replacing the name of a pagan god with the name of the Christian one, with the Virgin Mary or with the names of Christian saints, who assumed the function of pagan gods after the conversion of Slavs to Christianity (for the Serbian situation see: [ČAJKANOvić 1973: 153-154]), e.g.:

(1) a. 'to swear by Perun' > b. 'to swear by a saint'

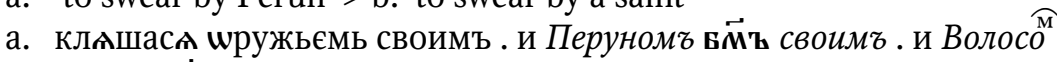
сKотьUМъ Б्रेOMъ [LAVR. 38],

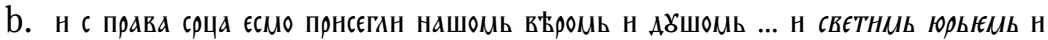
арханьгеломь Мнханяомь нашнмн крьстньмн нменн [MS CCIV, 1391];

(2) a. 'to be cursed by Perun > b. 'to be cursed by God and all the saints'

a. и да буде клАтъ $\overrightarrow{\boldsymbol{w}} \overrightarrow{\mathbf{E}} \mathbf{a}$ и $\boldsymbol{\mathbf { w }}$ Пєруна яко преступи свою клАтву [LAVR. 38],

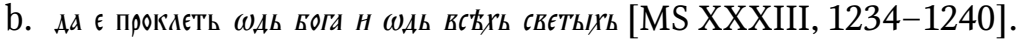

The syntactic structure of the formulaic phrases is entirely preserved: *klęti $(s e)+$ the instrumental; *byti proklętz + otb + the genitive, the second one being a "passive version" of the first one. In both cases the adjunct expresses the agent or the instrument which would execute the punishment in case of perjury [NĚMEC 1994: 377]. Cf. the following:

(3) да не имуть помощи $\overrightarrow{\boldsymbol{w}} \overrightarrow{\mathbf{E}} \mathbf{a}$ и да будеть рабъ въ весь в да заколенъ будеть своимъ шружьємъ [LAVR. 38].

Swearing on a weapon is known in other Indo-European traditions as well, witnessing to an ancient warrior weapon cult [WATKINS 1995: 417; WEST 2007: 463-462]. As for the broader Slavic tradition, it is worthwhile to notice that we find indirect evidence for swearing on the sword in Chronica Boemorum, written by Cosmas of Prague in the 12th century:

(4) Teste Marte deo et mea domina Bellona, quae mihi fecit omnia bona, per capulum ensis mei iuro, quem manu teneo [ChB: 24].

The South Slavic epic tradition testifies also to the swearing on a weapon:

(5) Kad ja pođem među družinicom zaklinjem se konjem i oružjem [GP Vuk VI 16.9-11]. ${ }^{7}$

On the other hand, formulas which did not contain a specific lexical element pointing to the old religion were preserved as such and incorporated into Christian discourse. Although they are of "neutral character", not mentioning a specific deity, the structure of a formulaic phrase can be very archaic, as in:

6 Although the question surpasses the aim of this investigation, it should be added that this formula appears in other traditions, too. It was obviously part of Jewish tradition as well, as testified to by the Old Testament: "And ye shall not swear by my name falsely, neither shalt thou profane the name of thy God: I am the lord”(Leviticus 19:12).

7 I would like to thank Aleksandar Loma for pointing out this example. 


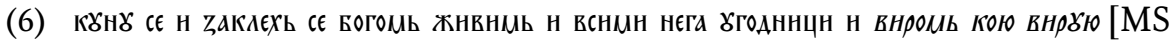
CCLV, 1410].

The construction with a restrictive relative clause (viroms koju viruju 'by the faith in which I believe') is reconstructed as an integral part of a Proto-IndoEuropean oath formula, as proven by the Slavic, Irish and Greek data [WATKINS 1989: 792].

Thus, besides the well-known "dualism" of Slavic culture [ToLstoJ, TOLSTAJA 1978: 366], in oath formulas we find their specific amalgam: the old patterns were kept and incorporated into the new cultural model of Christianity. ${ }^{8}$ The same amalgam is present in the swearing rituals as well [LSSV: 204-205].

There are different kinds of oath formulas in medieval Slavic charters. Their choice was determined, in the first place, by the type of charter and the textual models used in creating them, including foreign ones. For example, in Serbia the Byzantine influence was stronger than in Bosnia. This is obvious in the case of the formulas containing cělb 'whole': Bosnian charters, unlike those from Raška, were not under the direct influence of the Byzantine textual patterns, and the models for their composition were taken from the traditional, customary law [GRKOVIĆ-MAJOR 2008: 144]. There are also differences between Serbian and Russian charters: the formulas containing "krestnoe celovanie" (e.g. i mně tobě kr(e)stnoe cělovanie složiti [DDG: 201, 1461] are not found in Old Serbian documents.

The question of foreign influences on the formulas is certainly not easy to answer. Let us just take the example of the document Torgovyj dogovor Smolenska s Rigoju $i$ Gotskim beregom from 1229. There have been at least three different views about the possible foreign influences on it: a) the original text was German or Latin, then translated into Russian; b) only the introductory and the final parts exhibit foreign influences, due to the use of German and Latin textual models; c) the treaty was written in Russian by a man who new the language well but whose mother tongue was German [SG: 19]. The methodological view taken in this paper is that in order to reconstruct original Slavic formulas we need to: a) compare data from vernacular texts written in different parts of Slavdom which were exposed to different influences in this domain (German, Latin, Roman or Byzantine); b) find a system of formulas and their cultural motivation; c) see if such formulaic expressions exist in the oral tradition and in other vernacular documents.

8 We find this in several other domains as well, even in a specifically Christian domain of Serbian medieval literature: the vitae. According to A. Loma [Loma 2002: 158], the inclination of Serbs for this specific genre is a trace of pre-Christian custom to create epically intonated praise for distinguished deceased people. 


\section{Oath Formulas with 'Stand Firm' and 'Hold Firm': Linguistic Structure}

The attention of this paper is focused on the oath formulas which contain phrases 'stand (firm)' and 'hold (firm)'. In Old Serbian charters they usually appear in the sanction ${ }^{9}$ of the peace treaties: ${ }^{10}$

(7) 'stand firm'

стонте тврьдо / непокоКББнио 11

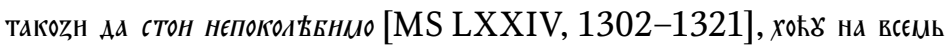
на томь Бншє Пнсанн

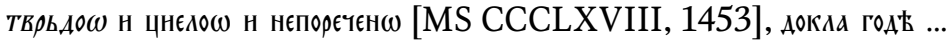

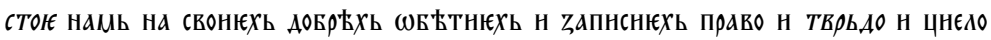
[MS CCCLXVIII, 1453];

$\begin{array}{ll}\text { (8) ‘hold } & \text { firm’ } \\ \text { (or(z))дрьжатн } & \text { тврьдо /непокольБнио/непомьнто }\end{array}$

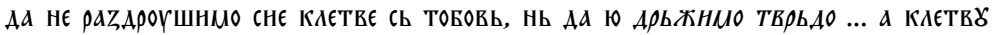

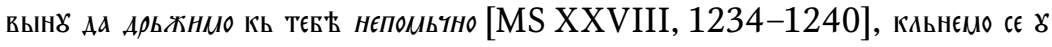

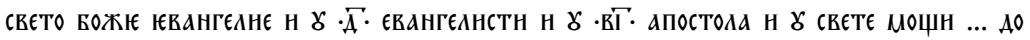

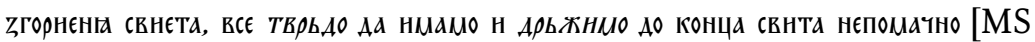

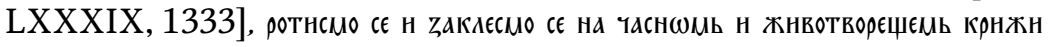

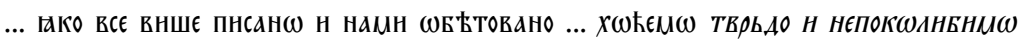
н непорочнШ ва внєка внєка

The notion 'firm' is most often denoted by the lexeme tvrbdo, but it can be replaced or followed by the synonymous words krěpsko, temelono, nepokolěbimo, nepomьčno. This indicates a ritual repetition of the same content in many different ways [ToLsTOJ 1995: 124]. Generally, as we have noted before, formulaic phrases exhibit lexical variation which points to their semantic compositionality. ${ }^{12}$

The formulas with 'stand' and 'hold' are found also in the exposition ${ }^{13}$ of the charters. It is noticeable that they are well attested in the documents from the 12th and 13th centuries, but that they rarely appear in the later period:

9 On the sanction as a part of medieval charters, especially in Old Serbian, see [STANOJEVIĆ 1922: 1-48].

${ }^{10}$ As in pre-Christian times, in Europe of the Middle Ages the oath was the crucial part of a peace treaty: "the oath for a long time remained the most important part of the reification process" [LESAffER 2004: 23]. Treaties were sworn upon not only when Christian rulers (from the same or different Christian churches) were involved, but also when the two parties represented different religions, as in the case of the peace treaties between the Ottoman Empire and the Christian states [ZIEGLER 2004: 339-341].

${ }^{11}$ We give one example for each varying lexical constituent as an illustration.

12 It should be noted that even in idioms, as emphasized by D. O. Dobrovol'sKiJ [2007: 30], "semantičeskaja členimost' idiomy korreliruet s vozmožnostjami ee var'irovanija".

${ }^{13}$ On the exposition in Old Serbian charters, see [STANojEvić 1920]. 
(9) 'stand in/on the oath /faith/law/peace/justice/promise'

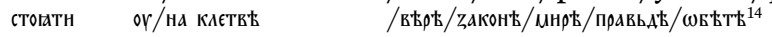

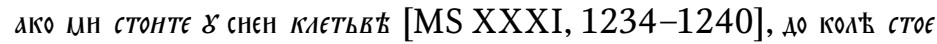
сь мновь 8 правьдћ [MS XXXIII, 1234-1240], кельнемо сє ... Аа вн

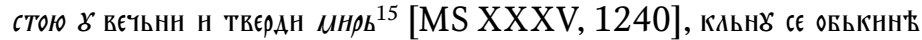
а Бровьтькон аа стою с вамн $\gamma$ мнрь н $\gamma$ свакУ правьд $\gamma$ [MS XXXVI,

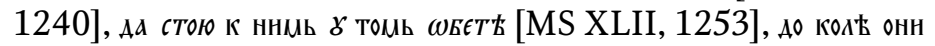

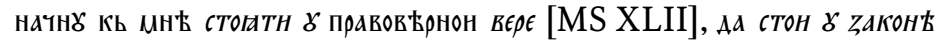
штьчннь мн [MS LXVI, 1254];

(10) 'hold the oath /faith/peace/law/friendship/promise' арьжатн клєтвог /вьрог/гон, иньь/цаконь/прнатьдьство/

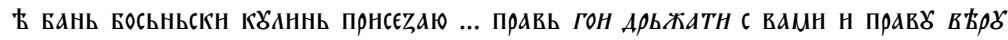

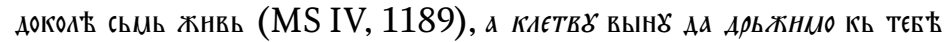
нємомьтно [MS XXVIII, 1234-1240], мн дрьжнмо вьрб н прнБтєАьство теББ н твонМь АУАєМь [MS XLIII, 1253], А९ьЖатн СН оБьть [MS XLI], н свето тн царьство аа АрьЖн намь старн законь [MS XLI, 1253].

The following phrase with the causative po-stav-iti, derived from the same root as stojati, belongs to the same conceptual domain:

(11) 'make stand the oath /faith/law/peace' поставнтн каетвог /вьрог/zаконь/мнрь а ннога новога zакона да нмь не поставн кралевьство мн [MS LIII, 1240-1272],

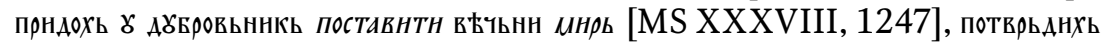
н поставнхь ш ннмин върб н кАєтв $\delta$ [MS CLXXIII, 1373].

The importance of the concept 'firm' is also testified to by the examples with optative semantics:

(12) 'let it be firm'

ал Іесть/воүає тврьдо /крьпько/непокольБншо/нераZорено/темельно

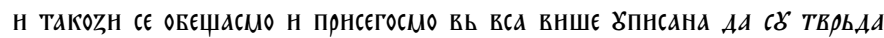

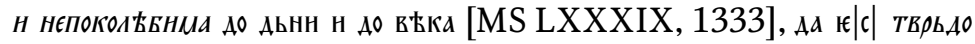

н неразооънно

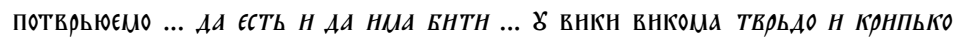

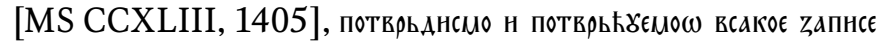

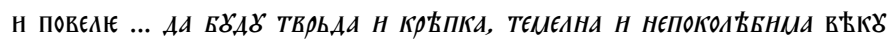
вькома [MS CCCLXXI, 1454].

As the antithesis to the 'firm standing' and 'firm holding' stands 'destroying/ breaking':

14 The lexeme obětb 'promise' is functionally identical with kletbva 'oath', as can be seen from the following example: да стою к ннмь $\gamma$ томь (бєеть, кониь ниь (с)ьмь сє клєль 'tо stand to him in that promise by which I swore' [MS XLII, 1253].

15 Besides the locative case, we also find the indirective accusative, but this is due to a later development (see [PAVLović 2006: 29-34]). 


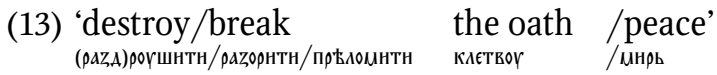

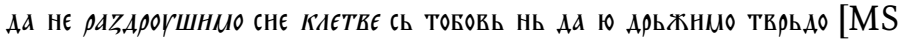

XXVIII, 1234-1240], Н кто сНЕ ПрНноМН ... АА БОГЬ сєПЬНЕ Н СвєТА вогороднца н вьсн светн [MS XXXV, 1234-1240], а Мнрь Аа се Нє рогшн

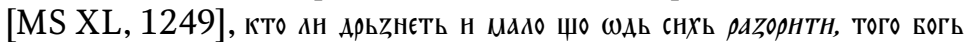
да разорнтьь гнЊвомь свонщь [MS LXV, 1305-1307].

Formulas of identical structure are found in Old Russian texts. The only difference is that, in Old Russian formulaic phrases, the dominant lexical exponent of the concept 'firm' is krěpsko (which is also frequent in the Western area of Štokavian):

$\begin{array}{ll}\text { (14) ‘stand } & \text { firm’ } \\ \text { стоя-ти/-ть } & \text { крепко /твердо/непорушено }\end{array}$

А старому миру столти кназ(я) Гердена кназ(ъ) тыих, кто по нем будет(ь) [POL: 85, 1268], про тожъ бы тое смиренье вечно столло непорушено со обою сторону межи нами полочАны и рижАны [POL: 113, 1407], како миръ оутвьржонъ и добросердьк [е] а бы вь въкы стояло [SG: 45, 1270-1277], тебе же, государю нашему, повинувшеся молению и доброй думе и обещавшуся крепко стояти за благочестивую нашу православную виру и оборонити свое отчьство [VPL: 267].

We can see that the formula spread beyond its original domain of swearing, appearing in optative constructions as well. Nevertheless, still in the 17th century it was functioning as an oath. In [SE 2004: 695] we find the following description of the preparations for an uprising at the beginning of the century, “здесь же составлялся договор вроде присяги, произносилось крестное целование в том, чтобы «дружно и крепко стоять за православную веру и Московское государство»" (17th century) (emphasis by JGM).

(15) 'hold firm'

(c)держа-ти(-ть) крепко /твердо/непорушено што ми то сдержати кр впко и до своего живота [SG: 72-73, 1386], обещаемся по истине твердо и крепко держаться, по правде и по чести [GVNP: 84, 1407], то имамь твердо и вечно держати, непор 8 шено на шбе стороне [POL: 75, 1478], сей мир положенных шесть лет держать по сей перемирной грамоте крепко [GVNP: 335, 1503].

(16) 'destroy stg.'

(на-/раз-/по-)руши-ти(-ть)

да шбачє будєть добр屯 Игорь вєликыи кнАзь . да хранить любовь вьсю правую . да нє раздрушитса дондєжє сл̈нцє сияє и всь миръ стоить [LAVR. 38], аж бы миръ не раздроушенъ 
былъ [SG: 21, 1229], кто нарушит это крестное целование пусть судит и накажет бог [GVNP: 70, 1326], а кто сю грамоту порушить, судить ему Бог [DDG: 8, 1339], а хто сю грамоту иметь рушити, судить ему б(ог)ъ [DDG: 14, 1353].

Even Old Church Slavonic testifies to the formulas with 'stand' and 'hold':

(17) 'stand (firm)'

стонатн (твръдь/Твръдо)

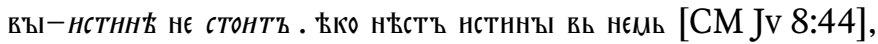

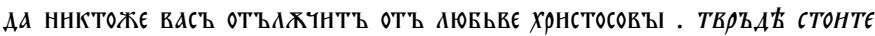

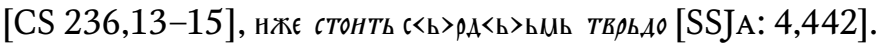

$\begin{array}{ll}\text { (18) 'hold } & \text { (firm)' } \\ \text { Аръжатн } & \text { (твръдь/Твръдо) }\end{array}$

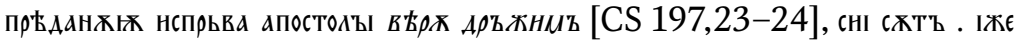
АОБРОМь СРЪАЬЦЕМЬ І БААГОМЬ . САЫШАВЪШЕ САОВО . АРЪЖАТЪ [CM Lk 8:15], н тврдА вєрнБ дрЖАтн ПодоБаєть [SSJA: 4,446].

In these cases, of course, we cannot exclude a direct Greek influence dur-

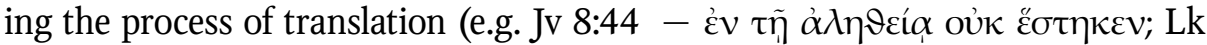

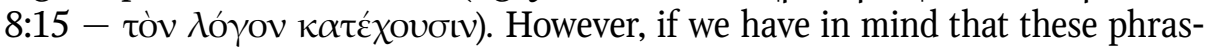
es exist in the documents written in Slavic vernaculars, we are not dealing with a calque, but rather with a choice of Slavic phrases which were equivalent with the Greek ones..$^{16}$ In Church Slavonic we also find the compounds tvrbdostavono, tvrbdostanije, tvrbdostojanije, tvrbdostojati etc. Most of the examples cited in [SSJa 4: 443-444] are from a text of Czech provenance translated from Latin (Gregorii Magni papae Homiliae in evangelia), and these lexemes have no correlative compounds in the original text, e.g.: vozljubi tvrbdostavbno stojati na sebe (lat. solide). This might prove that these formulas were alive among the Western Slavs, too.

It should also be added that the Serbian and Croatian oral traditions and different historical sources written in the vernacular testify to the phraseologisms 'hold (firm) X' and 'stand (firm) in/on X' [RJAZU 2: 829-830; 16: 345-348]. For more data from Russian see [SDRJa 1: 775-776; 3: 528-529].

On the basis of the data given we can conclude that these formulas are of Proto-Slavic origin. They might be presented in the following way (examples with *klętva):

${ }^{16}$ By "Greek constructions" we mean the constructions existing in the Greek text (which is relevant for Old Church Slavonic). A separate question, beyond the scope of this paper, concerns possible Aramaic influences in this domain, since the synoptic gospels were constructed on the basis of an Aramaic oral tradition. For more on this see [KüMMEL 1979, especially 47, 97, 121, 149]. The same phrases are attested to in the Old testament (cf. Your word, o Lord, is eternal; it stands firm in the heavens (Psalms 119:89)). It seems that we are dealing with phrases which existed in both the Indo-European and Semitic groups and were perhaps of a universal character. 
(19) *stojati tvrbdo/krěpbko vb/na klętvě ( $k r)$ komu;

*drъžati tvrbdo/krěpbko klętvo (kz) komu.

An analysis of the corpus shows that the lexical exponents of the key elements 'stand' and 'hold' do not undergo variation, unlike the other elements of the oath formulas.

\section{Cognitive Aspects}

PS *stojati is derived from PIE *stā- 'stehen, stellen' [PoKORNY 1959: 1004], 'wohin treten, sich feststellen' [LIV: 590]. Keeping in mind that *stojati is a stative verb, reflecting the second series of Proto-Indo-European (inactive $>$ ) medium verbs [IvANOv 1981: 160], its semantics would be 'stand upright, not moving' (cf. [RJAZU 16: 338]). This points to 'immobility' as its basic component.

PS *drbžati $(<*$ dheregh- 'halten, festhalten; fest' < *dher- [PокоRNY 1959: 25]; 'befestigen, fixieren' [LIV: 145]) is also a stative verb, as proven by the suffix * ${ }^{*}$ ( $\left.{ }^{*} d h e r g-\bar{e}-t i\right)$. According to [MALLORY, ADAMS 2006: 27] the basic meaning of the root is 'be immobile; support, hold up': "semantically, Old English, Greek and Armenian all point to a quality of immobility”. Slavic material should be added here as well.

The adjective *tvrzdz has the root *tuer- 'fassen, einfassen, einzäunen' [PoKoRny 1959: 1100-1101]; 'fassen' [LIV: 2001: 656]. Supposing that the formant $* d$ is a grammaticalized form of * $d h \bar{e}$ - 'put, place' [Vlajić-Popović 2000; GRKOVIĆ-MAJOR 2009] the basic semantic components of *tvrzdr would be 'hold + put, place' > 'make immobile'. The adjective could develop the metaphorical meaning 'lasting, durable, stable', denoting the quality of 'stability' [cf. Ivić 2008: 13].

In *krěpıkz we find *krēp-, attested only in German and Slavic [POKORNY 1959: 620]. Miklosich [MikLOsich 1886: 139] defined it as following: "die urspr. Bedeutung des Wortes krêpz ist starr, fest”. Although the prevailing semantics in Slavic languages today is 'strong', Old Slavic documents still preserve the primary meaning (cf. [ËSSJA 12: 135-138]). As the first meaning for krepak in Serbo-Croatian RJAZU [RJAZU 18: 512] gives the following explanation: tvrd, čvrst, postojan, stalan, koji se ne da pomjeriti... 'hard, solid, stable, constant, which cannot be moved..., and for the adverb krepko gives: ne mičuć $i$ se 'not moving' (= immovably).

As revealed by the etymology of their lexical constituents, the key concept in the formulaic phrases *stojati tvrbdo / krěpsko and *drbžati tvrıdo / krěpьko is 'immobility, firmness'. This has a deep cultural motivation, since 'immobility', 'firm standing' and 'firm holding' are key Proto-Indo-European cultural concepts. As V. N. Toporov [Toporov 2004: 479] has noted, 'to stand' belongs to the group of predicates with cosmogonic character. These notions define 
the basic parameters of existence, both of the universe and of the human community. 'Standing' is connected with 'existence' even linguistically. For example, we find Lat. stare 'stand' as a synonym for esse 'exist, be' [ERNOUT, MEILlEt 1951: 651), kelt. *tā-yo 'stand' > MW -tau 'is' [MATASOvić 2009: 373], Old Church Slavonic stojati means both 'stand' and 'exist, be' [SSJa 4: 170], in [SDRJa 3: 34] under stojati we also find the meaning "byt', deržat'sja" and under stojatisja - "byt', suščestvovat", in Serbian and Croatian sources stajati has the semantics "esse, existere, bestehen" [RJAZU 16: 348]. While the PIE *es- 'exist, be' was being grammaticalized into a copula, new words for 'exist' in some Indo-European languages were created on the basis of *stā-: Lat. existo, Germ. bestehen, Serb. postojati etc.

In different Indo-European traditions 'the world stands' because a deity 'holds it', as testified to by different traditions, e.g. Lat. omnia per sonitus arcet terram mare caelum '(Jupiter, who) holds all by thunder, earth, sea, heaven' [Punvel 1991: 156], Av. kasnā daratā ząmca adō nabåscā avapastōiš 'who holds the earth below and the heavens from falling' [YASNA: 44.4] etc. ${ }^{17} \mathrm{Al}-$ though some of these references to axis mundi are figurative, "it is a plausible assumption that behind this abstract imagery lies a more primitive concept of a world pillar that held up the sky like the timber prop of a house or yurt" [WEST 2007: 345]. When this original vision was abandoned, the expression transformed into a formula [CHRISTOL 2006: 52].

In Slavic mythology the world tree is the representation of the entire universe [SM: 163]. We find a reflection of that in the phrase mirb $/$ svert $^{18}$ stoits 'the world stands (> exists) ', which is an integral part of Slavic oath formulas, both Old Russian and Old Serbian:

(20) створити любовь ... на всл льта дондеже слінце сияеть . и всь мирь стоить [LAVR. 34], да нє раздрушитсл дондєжє сллнцє сикєе . и всь мирг cmoumb [LAVR. 38],

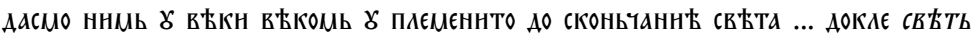
стонть [MS CCXXV], потврьдн $\curlyvee$ внкн внкома ... Ао колн свнть стон [MS CCXLIII, 1405].

On a societal level, a community 'stands' because a ruler 'stands' and a contract among people is 'held', guaranteeing social structure. A ruler is thus a human counterpart of a deity, since "Le rex indo-européen est beaucoup plus religieux que politique. Sa mission n'est pas de commander, d'exercer un pouvoir, mais de fixer des règles, de déterminer ce qui est, au sens propre, «droit». En sorte que le rex ainsi défini, s'apparente bien plus à un prêtre qu'à un souverain" [BENVENISTE 1969, II: 15]. In Vedic texts about the celebration of the king, for example, a domi-

\footnotetext{
${ }^{17}$ For more about this see [WeSt 2007: 340-341, 345-346]. This is a wide-spread concept in other traditions, too (see e.g. [HultKranz 1996]).

18 On the semantic history of these two words, see [TOLSTAJA 2010].
} 
nant formula is 'stand firm': dhruvás tiștha [Toporov 2006: 661-662]. And a society is protected because Indo-European heroes stand firm in battle like a rock, a stone, a mountain or an oak, as revealed by the poetry [WEST 2007: 458].

The importance of the other concept, 'hold', is seen in other traditions as well, even with the same etymon as in Slavic. In Indo-Iranian we find the root *dher- in one of key notions both in Hinduism and Buddhism, dhárma'law, custom, rule etc.', loc. dhárimani 'according to law, rule' [BENVENISTE 1969, I: 101]. Av. dar- is 'hold', but 'hold to the rule, law' as well [РокоRnY 1959: 252]. According to the explanation given by V. L. CYMBURSKIJ [2008: 180-187], Lat. forma is semantically and formally connected with Vedic dhár-

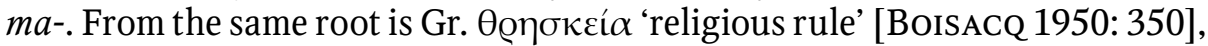

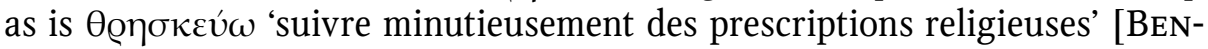
VENISTE 1969, II: 267]; E. Benveniste also noticed that this term belonged to the practice of rituals. Lith. dermẽ is 'contract', dorà 'morality', dernà 'harmony' [FRAENKEL 1962-1965, I: 83].

An episode from Herodotus is illustrative for the oath ritual, perhaps revealing the close Slavic-Iranian relations in this domain..$^{19}$ During the making of the peace treaty between the Persians and the Barcaeans the following was said:

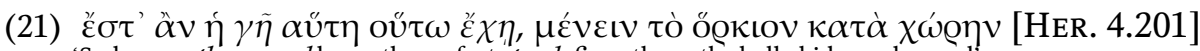
'So long as the ground beneath our feet stands firm, the oath shall abide unchanged'.

This episode is valuable for the analysis of 'stand' and 'hold', too. Gr. é $\chi \omega$ (<*segh $h$-) belongs to the group of absolute verbs: used "intransitively" it means 'hold oneself, stand' ( $>$ 'be, exist'), and used "transitively" - 'hold' ( $>$ 'have') [GEL: 750]. ${ }^{20}$ This shows that 'hold' ('make immobile') is just a transitive variant of 'stand' ('be immobile'), indicating again the core concept of 'immobility'. The metaphorical extension of these two concepts points to the same: 'be' and 'have' express the same notion (possession) in different ways. Giving the example of French avoir, E. BENVENISTE [1975: 153] argues that this verb has a transitive construction but that it is a stative verb, nothing else but être-à "inverted".

If we compare the two aforementioned examples from the Old Serbian documents we can see the same "inversion" in the case of stajati and držati:
(22) ако мн стонтє 8 снен кАєтьвь
$=$ stand
in the oath
+ Dat,

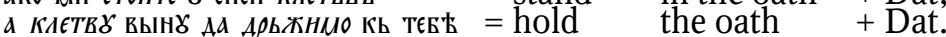

The difference between the two formulas is in the role of the actant. In the first (intransitive) one, the actant is responsible for keeping the oath by its own immobility, he 'stands in the oath', but he cannot act directly upon it; in the

19 The impact of Iranian elements in Proto-Slavic culture is well-known, especially in the domain of religion [MEILLET 1926] and epics [LOMA 2002]. The oath formula given here probably exemplifies close Slavic-Iranian relations in the sphere of the ritual practice of swearing.

${ }^{20}$ For more on the verb 'have' in Indo-European languages, especially in Slavic, and its development see [GrKović-MAJOR 2011b]. 
second (transitive) one, the actant is an agent who has an active role, he 'holds the oath' and acts upon it, he 'has it'. ${ }^{21}$

The structural and conceptual difference between the two formulas shows an important parallel to the presumed typological development of Proto-IndoEuropean and its daughter languages: a drift from a topic-oriented toward an agent-oriented language [LEHMANN 2002: 100-103], and the development of both semantic and syntactic transitivity [GAMKRELIDZE, IVANOV 1984, I: 312; for Slavic: GRKOvić-MAJOR 2010]. From a cognitive perspective, the topicoriented and the agent-oriented types, thus the two formulas just mentioned, reflect a different Weltanschauung:

"Agent orientation reflects our role as sentient, willful creatures forcefully acting on the world, expending energy to achieve and maintain control of our surroundings. Theme orientation reflects the fact that we operate in a world laid out in a certain way" [LANGACKER 2008: 366-367].

The root *stā-, widely attested for 'stand' in Indo-European languages, was undoubtedly inherited from the proto-language. On the other hand, the roots for 'hold' differ significantly [BUCK 1949: 746-747], meaning that the words for this "transitive" concept must have arisen later. Thus we may assume that Proto-Slavic oath containing the verb 'stand' must have been inherited from the deepest Proto-Indo-European stratum, when the oath was considered to be a force outside of man upon which he could not act directly.

'(Firm) standing' and '(firm) holding' belong to some of the basic IndoEuropean (and not just Indo-European) conceptual metaphors. Firmness and immobility are also evaluatives since they are a manifestation of health, strength and durability, whether a human being, an animal, a plant, a tool or a weapon is in question, and all these aspects were crucial to man's survival. The same conceptual metaphors were used for the notion of 'health', for example [GRKović-MAJOR 2011a]. These concrete, physical concepts, mapped into the target domain of the abstract concepts, represent the embodied experience and speak in favor of Embodied Realism, which "in contrast to Representationalist theories, rejects the notion that mind and body are two ontologically distinct kinds" [JOHNSON, ROHRER 2007: 17].

We believe that the analysis given here also confirms that the space between the domains of 'physical' and 'mental' is fuzzy not only synchronically, but diachronically as well. Historically, the transition from a 'concrete' to an 'abstract' concept was gradual: the key components of the formulas in question originally referred to concrete, physical notions of 'standing' and 'holding' and they gradually became conceptual metaphors, as the physical axis

${ }^{21}$ The verb * $d b \check{z} a t i$ is metaphorically mapped into 'have, possess' (see [SDRJA 1: 775; RKSS 1: 310-311]). 
mundi was becoming a figurative concept. This speaks in favor of fuzziness as being inherent to natural human language [RADOvANOvić 2009: 43].

It is understandable why these key cultural concepts were incorporated into Proto-Slavic oath formulas. They were so deeply rooted into the conceptual apparatus that they survived the change of cultural codes, becoming an integral part of the oath in Christian times. As time went by, they were secularized and reduced to phraseological units. They still exist today, even with the same lexical constituents as in the medieval charters, e.g. Serb. držati X (reč, obećanje, veru) [RMS 1: 778], Russ. sderžat'X (danoe slovo, kljatvu), stojat' na $X=$ tverdo deržat'sja $X$ (ubeždenija, mnenija) [SRJA: 698, 761]. As argued at the beginning of this article, in order to understand and explain contemporary linguistic systems we have to look back into their past.

\section{References}

\section{BENVENISTE 1969}

Benveniste É., Le vocabulaire des institutions indo-européennes, 1-2, Paris.

BENVENIST 1975

Benvenist E., Problemi opšte lingvistike, Beograd.

BOISACQ 1950

BoIsACQ É., Dictionnaire étymologique de la langue grecque, Heidelberg.

BuCK 1949

Buck C. D., A Dictionary of Selected Synonyms in the Principal Indo-European Languages,

Chicago, London.

$\mathrm{CHB}$

Die Chronik der Böhmen des Cosmas von Prag/Hrsg. B. Bretholz, Berlin, 1923. http://www. dmgh.de/de/fs1/object/display/bsb00000683_00122.html?sortIndex=010\%3A060\%3A0002 $\% 3 \mathrm{~A} 010 \% 3 \mathrm{~A} 00 \% 3 \mathrm{~A} 00>10.01 .2012$.

CHRISTOL 2006

Christol A., "Le voile de la nuit: de la poétique au lexique", in: Actes du Colloque de travail de la Société des Études Indo-Européennes (Indogermanische Geselschaft. Society for Indo-European Studies), Paris, 22-24 octobre 2003, Paris, 35-54.

$\mathrm{CM}$

V. JaGIĆ (ed.), Codex Marianus glagoliticus, Graz, 1960 (reprint).

CS

S. Severjanov (ed.), Codex Suprasliensis, Graz, 1956 (reprint).

CYMBURSKIJ 2008

Cymburskij V.L., "Latinskij trilistnik”, in: N. N. KazAnskij (red.), Colloquia classica et indogermanica, IV: Klassičeskaja filologija i indoevropejskoe jazykoznanie, Sankt-Peterburg, 169-220. 


\section{ČAJKANOVIĆ 1973}

ČAJKANOvić V., Mit i religija u Srba, prir. V. Đurić, Beograd.

\section{DDG}

Duchovnye i dogovornye grammoty velikich i udel'nych knjazej XIV-XVI vv., Moskva, 1950.

DOBROVOL'SKIJ 2007

Dobrovol'sKIJ D. O., “Leksiko-sintaksičeskoe var'irovanie vo frazeologii: vvod opredelinija v strukturu idiomy”, Russkij jazyk v naučnom osveščenii, 14, 18-47.

\section{ERE}

J. Hastings, H. S. Selbie, L. H. Gray (eds.), Encyclopedia of Religion and Ethics, 1-12, New York, Edinburgh, 1908-1922.

ERNOUT, MEILlet 1951

ERnout A., Meillet A., Dictionnaire etymologique de la langue latine. Histoire des mots, Paris.

ÈSSJA

Ėtimologičeskij slovar' slavjanskich jazykov, 1-, Moskva, 1974-.

FARAONE 2005

FARAONE CH. A., "Curses and Blessings in Ancient Greek Oaths", Journal of Ancient Near Eastern Religions, 5, 139-156.

FRAENKEL 1962

FRAENKEL E., Litauisches etymologisches Wörterbuch, I, Heidelberg, Göttingen.

GAMKRELIDZE, IVANOV 1984

GAMKRELIDZE T. V., IVANov VJač. Vs., Indoevopejskij jazyk i indoevropejcy, I-II, Tbilisi.

GEL

LidDel H. G., Scott R., A Greek-English Lexicon, Oxford, 1985.

GiBBs 2007

GibBs R.W. JR., "Idioms and Formulaic Language”, in: D. GeEraets, H. CuYcKens (eds.), The Oxford Handbook of Cognitive Linguistics, Oxford, 697-725.

GP

Guslarske pesme, <http://guslarskepesme.com/component/option,com mtree/task,listcats/cat_id,433/Itemid,/> 07.04.2011.

GRKOVIĆ-MAJOR 2008

GRKović-MAJOR J., "Formule s pridevom cělb u starosrpskim poveljama”, in: P. PIPER, LJ. RADENKOvić (ur.), Etnolingvistička proučavanja srpskog i drugih slovenskih jezika. U čast akademika S. Tolstoj, Beograd, 139-146.

GRKOVIĆ-MAJOR 2009

GRKoviĆ-MAJOR J., “O doprinosu jezičke tipologije etimološkim istraživanjima”, in:

I. JANYŠKovÁ, H. KarlikovÁ (eds.), Studia etymologica Brunensia, 4, Praha, 113-121.

GRKOVIĆ-MAJOR 2010

GrKović-MAJOR J., “Kognitivni aspekti razvoja tranzitivnosti”, in: J. GRKović-MAJOR,

M. Radovanović (ur.), Teorija dijahronijske lingvistike i proučavanje slovenskih jezika, Beograd, 43-62.

GRKOVIĆ-MAJOR 2010A

GRKOVIĆ-MAJOR J., "O praslovenskim formulama zaklinjanja u starosrpskim poveljama”, Susret kultura, 2, Novi Sad, 451-461.

GRKOVIĆ-MAJOR 2011A

Grković-MAJOR J., “Pojam zdravlja u indoevropskim jezicima”, Anali Ogranka SANU u Novom Sadu, 6, 26-37. 
GRKOVIĆ-MAJOR 2011B

GrKović-MAJOR J., "The development of predicative possession in Slavic languages”, in: M. NomAchi (ed.), The Grammar of Possessivity in South Slavic Languages: Synchronic and Diachronic Perspectives, Sapporo, 35-54.

\section{GVNP}

A. N. VALK (red.), Gramoty Velikogo Novgoroda i Pskova, Moskva, Leningrad, 1949.

\section{HAUDRY 1981}

HAUDRY J., Les Indo-Européens, Paris.

HER.

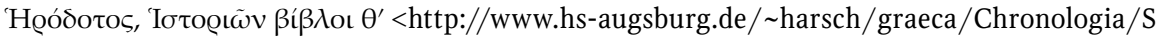
_ ante05/Herodot/her_intr.html > 24.03.2011.

HES.

HesioD, Works and Days $<$ http://www.perseus.tufts.edu/hopper $/$ text?doc=perseus $\% 3$ atext\% 3a1999.01.0131> 10.01.2012.

\section{HulTKRANZ 1996}

Hultkranz Å., "A new look at the word pillar in Arctic and Sub-Arctic religions", in: J. PentikÄInen (ed.), Shamanism and Northern Mythology, Berlin, 31-50.

IVANOV 1981

IVANOV VJAČ. Vs., Slavjanskij, baltijskij i rannebalkanskij glagol. Indoevropejskie istoki, Moskva.

IVANOV, TOPOROV 1974

IVANov V. V., Toporov V.N., Issledovanija v oblasti slavjanskich drevnostej. Leksičeskie $i$ frazeologičeskie voprosy rekonstrukcii tekstov, Moskva.

IVANOV, TOPOROV 1978

IvANOv V.V., ToPOROv V.N., “O jazyke drevnego slavjanskogo prava (k analizu ključevych terminov)”, in: Slavjanskoe jazykoznanije. VIII meždunarodnyj s"ezd slavistov. Doklady sovetskoj delegacii, Moskva, 221-238.

IVANOV, TOPOROV 1981 IVANOv V.V., TOPOROV V.N., Drevnee slavjanskoe pravo: archaičnye mifopoetičeskie osnovy $i$ istočniki v svete jazyka. Formirovanije rannefeodal'nych slavjanskich narodnostej, Moskva.

Ivić 2008

Ivić M., “O izrazu tvrd”, Zbornik Matice srpske za filologiju i lingvistiku, 51/1-2, 11-15.

JOHNSON, ROHRER 2007

Johnson M., Rohrer T., "We are live creatures: Embodiment, American Pragmatism and the Cognitive Organism”, in: T. Ziemke, J. Zlatev, R. M. Frank (eds.), Body, Language and Mind, I: Embodiment, Berlin, New York, 17-54.

KASIRER 1985

KASIRER E., Filozofija simboličkih oblika, II: Mitsko mišljenje, Novi Sad.

KATIČIĆ 1985

KATIČIĆ R., "Ispraviti pravbdo", Wiener Slavistisches Jahrbuch, 31, 41-46.

KATIČIĆ 1989-90

KATIČIĆ R., "Praslavenski pravni termini i formule u Vinodolskom zakonu”, Slovo, 39-40, 73-85.

KÜMMEL 1975

KüMmEL W.G., Introduction to the New Testament, London.

LANGACKER 2008

LANGACKER R. W., Cognitive Grammar. A Basic Introduction, Oxford. 


\section{LANGDON, GARDINER 1920}

LANGdon S., Gardiner A.H., "The Treaty of Alliance between Hattušili, King of the Hittites, and the Pharaoh Ramesses II of Egypt”, The Journal of Egyptian Archaeology, 6/3, 179-205.

LAVR.

Polnoe sobranie russkich letopisej, I: Lavrent'evskaja letopis', Leningrad, 1926-1928.

LEHMANN 2002

Lehmann W.P., "Pre-Indo-European”, Journal of Indo-European Studies, Monograph 41, Washington.

\section{LESAffER 2004}

LESAffer R., Peace treaties from Lodi to Westphalia”, in: R. LESAffer (ed.), Peace Treaties and International Law in European History. From Late Middle Ages to World War One, Cambridge, 9-44.

\section{LIV}

Lexicon der indogermanischen Verben. Die Wurzeln ind ihre Primärstammbildungen, Wiesbaden, 2001.

\section{LOMA 2002}

Loma A., Prakosovo. Slovenski i indoevropski koreni srpske epike, Beograd.

\section{LSSV}

S. ĆIRKović, R. MinaLjČIĆ (prir.), Leksikon srpskog srednjeg veka, Beograd, 1999.

\section{MALLORY, ADAMS 2006}

MALlORY J. P., AdAMS D. Q., The Oxford Introduction to Proto-Indo-European and the ProtoIndo-European World, Oxford.

MATASOVIĆ 2009

MATASOvić R., Etymological Dictionary of Proto-Celtic, Leiden, Boston.

\section{MEILlet 1926}

Meillet A., "Le vocabulaire slave et le vocabulaire indo-iranien", Revue des études slaves, 6/3-4, 165-174.

\section{Mićović 1981}

Mićović D., Albanske junačke pesme, Priština. <http://www.rastko.rs/rastko-al/prevodi/ albanske-junacke.php\#_Toc3479983> 29.03.2011.

\section{MiKLOSICH 1886}

MikLosich Fr., Etymologisches Wörterbuch der slavischen Sprachen, Wien.

MOKIENKO 2010

MOKIENKo V. M., “Istoričeskaja frazeologija slavjanskich jazykov”, in: J. GRKović-MAJOR, M. Radovanović (ur.), Teorija dijahronijske lingvistike i proučavanje slovenskih jezika, Beograd, 103-129.

MS

Miklosich Fr., Monumenta serbica. Spectantia historiam Serbiae Bosnae Ragusii, Graz, 1964 (reprint).

\section{NĚMEC 1994}

NĚMEC I., "The Potential Valency Constituent in Diachronic Lexicology”, in: S. ČMEJRKovÁ, FR. ŠTíchA (eds.), The Syntax of Sentence and Text. A Festschrift for František Daněs, Amsterdam, Philadelphia, 375-382.

PAVlović 2006

Pavlović S., Determinativni padeži u starosrpskoj poslovnopravnoj pismenosti, Novi Sad.

POKORNY 1959

POKORNy J., Indogermanisches etymologisches Wörterbuch, Bern, München. 
POL

A. L. ChorošKevič (sost.), Polockie gramoty XIII - načala XVI vv., Moskva, 1977.

Puhvel 1991

Punvel J., Hittite Etymological Dictionary, 3: Words beginning with H, Berlin, New York.

RADOVANOVIĆ 2009

Radovanović M., Uvod u fazi lingvistiku, Novi Sad.

RJAZU

Rječnik hrvatskoga ili srpskoga jezika, I-XXIII, Zagreb, 1880-1976.

RKSS

DANIČIĆ Đ., Rječnik iz književnih starina srpskih, 1-3, Beograd, 1863-1864.

RMS

Rečnik srpskohrvatskoga književnog jezika, I-III, Novi Sad, Zagreb, 1967-1969; IV-VI, Novi Sad, 1971-1976.

SDRJA

SREZneVSKIJ I. I., Materialy dlja slovarja drevne-russkogo jazyka po pis'mennym pamjatnikam,

1-3, Sankt-Peterburg, 1893-1912.

SG

R. I. Avanesov (red.), Smolenskie gramoty, Moskva, 1963.

SE

V. V. BoguslavskiJ (avt.-sost.), Slavjanskaja ènciklopedija. XVII vek, 1-2, Moskva, 2004.

SM

S. M. Tolstoj, LJ. Radenković (red.), Slovenska mitologija. Enciklopedijski rečnik, Beograd, 2001.

SPP

StojAnović LJ., Stare srpske povelje i pisma, I/1-2 (= Zbornik za istoriju, jezik i književnost srpskog naroda, XIX), Beograd, 1929-1934.

SRJA

OžEgov S. I., Slovar' russkogo jazyka, Moskva, 1963.

SSA

Stari srpski arhiv, 1-, Laktaši, 2002-.

SSJA

Slovar' staroslavjanskogo jazyka (reprintnoe izdanie), 1-4, Sankt-Peterburg, 2006.

STANOJEVIĆ 1920

StANOJEviĆ St., "Studije o srpskoj diplomatici. VIII. Ekspozicija (Naracija)", Glas SKA, XCVI, Drugi razred, 56, 117-141.

STANOJEVIĆ 1922

StANojević St., "Studije o srpskoj diplomatici. X. Sankcija”, Glas SKA, C, Drugi razred, 58, 1-48.

Tolstaja 2010

Tolstaja S. M., "K semantičeskoj istorii slav. *mirz $i$ *světz", in: J. Grković-Major, M.

RAdovanović (ur.), Teorija dijahronijske lingvistike i proučavanje slovenskih jezika, Beograd, 199-213.

Tolstoj 1995

Tolstoj N. I., Jezik slovenske kulture, Niš.

Tolstoj, Tolstaja 1978

Tolstoj N. I., Tolstaja S. M., “K rekonstrukcii drevneslavjanskoj duchovnoj kul'tury (lingvoi ètnografičeskij aspekt)”, in: Slavjanskoe jazykoznanie. VIII meždunarodnyj s"ezd slavistov.

Doklady sovetskoj delegacii, Moskva, 364-385. 


\section{TOPOROV 2004}

ToPorov V. N., Issledovanija po ètimologii i semantike, 1: Teorija i nekotorye častnye ee priloženija, Moskva.

Toporov 2006 TOPOROV V. N., Issledovanija po ètimologii i semantike, 2/1: Indoevropejskie jazyki i indoevropeistika, Moskva.

VLAJIĆ-Popović 2000

VLAJIĆ-PopoviĆ J., "Some Slavic Etymologies Reconsidered, Formal and Semantic Guidelines”, in: I. JANYŠKovÁ, H. KARLIKovÁ (eds.), Studia Etymologica Brunensia, 1, Praha, 191-199.

VPL

M. N. Tinomirov (red.), Polnoe sobranie russkich letopisej, 26: Vologodsko-Permskaja letopis, Moskva, Leningrad, 1959.

WATKINS 1989

WATKIns C., "New Parameters in Historical Linguistics, Philology and Culture History", Language, 65/4, 783-799.

WATKINS 1992 Watkins C., "The Comparison of Formulaic Sequences", in: E. C. PolomÉ, W. Winter (eds.), Reconstructing Languages and Cultures, The Hague, 391-418.

WATKINS 1995 Watkins C., How to Kill a Dragon. Aspects of Indo-European Poetics, Oxford.

WEST 2007 West M. L., Indo-European Poetry and Myth, Oxford, 2007.

YASNA

(Based on: K. F. Geldner (ed.), Avesta, the Sacred Books of the Parsis, Stuttgart, 1896)

$<$ http://www.avesta.org/yasna/y43to46.htm> 27.03.2011.

\section{ZA}

J. DARmesteter (transl.), The Zend-Avesta, I: The Venidad, Oxford, 1880.

\section{ZIEGLER 2004}

ZIEGLER K.-H., "The peace treaties of the Ottoman Empire with European Christian Powers", in: R. LESAffER (ed.), Peace Treaties and International Law in European History. From Late Middle Ages to World War One, Cambridge, 338-364.

\section{ZS}

NovaKović ST., Zakonski spomenici srpskih država srednjega veka (= Posebna izdanja SKA, 37), Beograd, 1912.

Prof. Jasmina Grković-Major, PhD

Odsek za srpski jezik i lingvistiku

Filozofski fakultet

Univerzitet $\mathrm{u}$ Novom Sadu

Dr Zorana Đinđića 2

21000 Novi Sad

Serbia

jgrkovicns@sbb.rs 